\title{
"Home to Harlem, Away from Harlem": Transnational Subtexts in Nella Larsen's Quicksand and Claude McKay's Home to Harlem
}

\begin{abstract}
Heeding Brent Hayes Edwards 2003 call to re-examine African American writings of the early twentieth century within the context of emergent transnational sentiments, this article explores the literary depictions of transmigrant characters in Nella Larsen's Quicksand (1928) and Claude McKay's Home to Harlem (1928). Written and set during the volatile interwar years, Quicksand and Home to Harlem complicate and expand upon Randolph Bourne's "Trans-National America" (1916) and Alain Locke's "Harlem" (1925) by exploring how the transnational experience of moving away from, into, and between communities transforms existing identity concepts and creates spaces for the generation of self-definitions that are not bound by traditional notions of national and racial belonging.
\end{abstract}

Key words

Alain Locke; Randolph Bourne; identity politics; nationalism; cosmopolitanism; Harlem; New Negro

When first published in 1928, Nella Larsen's Quicksand and Claude McKay's Home to Harlem attracted instant attention for their depictions of racism and black sexuality. Reviewing both novels in the Crisis, W.E.B. Du Bois praised Larsen's Quicksand as "a fine, thoughtful, and courageous piece of work," while sharply disapproving of McKay's Home to Harlem for catering to "that prurient demand on the part of white folk for a portrayal in Negroes of that utter licentiousness which conventional civilization holds white folk back from enjoying" (Du Bois 1928: 202).

Du Bois's joint book review set the tone for the initial reception of Quicksand and Home to Harlem. Larsen's portrayal of Helga as a tormented yet chaste 
woman, who feels ill at ease amidst the licentiousness of Harlem, was seen by many critics of the day as an uplifting antidote to the alleged endorsement of harmful primitivism in McKay's Home to Harlem. Later critics, much less inclined to bestow uplifting literary models with identity-political currency, started lauding Quicksand for its daring exploration of the mechanisms of sexual oppression while upholding Home to Harlem as a self-affirmative expression of African American sensuality.

Until fairly recently, however, little critical attention has been paid to the ways in which these two Harlem Renaissance novels thematize oppression and selfexpression before the backdrops of imperialism and global migration. Even Du Bois, who in a 1906 Colliers Weekly article had declared that the "Negro problem" in the United States is "but a local" manifestation of "the color line [that] belts the world," seems to have missed the transnational subtexts of Larsen's Quicksand and McKay's Home to Harlem (1995: 42). One reason for this apparent critical oversight might be that influential studies ranging from Nathan Irvin Huggins's Harlem Renaissance (1973) to Ann Douglas's Terrible Honesty: Mongrel Manhattan in the 1920s (1996) have tended to describe the Harlem Renaissance as a local phenomenon, whose struggles with questions of cultural nationalism, civil rights, and race relations were confined to the US American scene. Noting that the "Renaissance" was "international in scale" and "merely the North American component of something larger and grander," Brent Hayes Edwards has urged critics to re-examine African American writings of the early twentieth century within the context of emergent transnational sentiments (2003: 3). Shelley Fisher Fishkin issued a similar call in 2004, arguing that "as the transnational becomes more central to American studies, we are likely to focus not only on the proverbial immigrant who leaves somewhere called 'home' to make a new home in the United States, but also on the endless process of comings and goings that create familial, cultural, linguistic, and economic ties across national borders" (2005: 24).

Unlike earlier Harlem Renaissance novels such as Jean Toomer's Cane (1923) and Jessie Fauset's There is Confusion (1924), Quicksand and Home to Harlem trace the emergence of the New Negro spirit in deliberately transnational terms that expand and further complicate Du Bois's concept of "double-consciousness," which he famously described as a feeling of "two-ness, - an American, a Negro" (1996: 3). Nella Larsen, a self-described mulatto daughter "of a Danish lady and a Negro from the Virgin Islands, formerly the Danish West Indies" (qtd. in Davis 1994: xviii), uses Quicksand to present the American reading public with a protagonist who is "neither black nor white" and equally unable to identify with the "amazing orderliness" of Copenhagen (57) and the "feverish rush" of New York City (38). Helga's attempt to find herself in a place where there are "no Negroes, no problems, no prejudice" is cut short when she realizes that Danish society merely exploits her as an exotic other (68). Helga eventually returns to the United States and settles down in rural Alabama, where she finds herself estranged from the local community and drowns in the quicksand of life-threatening pregnancies. 
In Home to Harlem, the Jamaican-born author Claude McKay, who admonished critics of the novel "to look a little into my obscure life" (2005: 301), tells a similar migration story that depicts the struggles of Ray, a young Haitian intellectual, who is at once fascinated by the vitality of Harlem and repulsed by the parochialism of its inhabitants, few of whom are aware of the recent US occupation of his homeland. Fearful that he might become "one of the contented hogs in the pigpen of Harlem," Ray leaves his US American girlfriend and heads for an uncertain future in Europe (196).

Central to both novels is the perilous quest for a transnational identity that transcends not just national parochialisms, but ethnic and racial stereotypes as well. Though under different circumstances, both Larsen's Helga and McKay's Ray come to embody the promises as well as the pitfalls inherent in Alain Locke's proclamation of Harlem as "a race capital," where "Negro life is seizing upon its first chances for group expression and self-determination" (1925b: 629). For while Locke's recognition of the importance of the African and West Indian presence in Harlem points toward the possibility of a pluralistic society that embraces differences, his subsequent linking of Harlem to the capitals of newly created European nation-states presupposes a model of national identity that is not available to Haitian transmigrants such as Ray in Home to Harlem and Danish African Americans such as Helga in Quicksand. As Michelle Stephens explains, unlike "Polish, Slovak, or Czech immigrants, who could conceive of themselves as sharing a particular linguistic and cultural heritage which had grown and developed within a single geographical territory," Caribbean "immigrants in the United States had uncertain ethnic identities, unimaginable really in national terms" (1998: 597). Exposing the limits of what Laura Doyle has described as a "transnationalism authorized by the nation," McKay's Home to Harlem and Larsen's Quicksand complicate libratory notions of transnationality by "question[ing] the freedom promised not only by nations and empires but also specifically by the transnational mobility that constitutes them" (2005: 555).

By the 1920s few people could have failed to notice that the Great War had shaken the foundations of an imperial world order, established and maintained by a handful of European powers since the early nineteenth century. In the aftermath of the war, the United States flexed its muscles as the newest power on the world stage, the fledgling Soviet Union presented socialism as a viable alternative to capitalism, and across the globe nationalist movements, as diverse as the Indian National Congress and Marcus Garvey's Universal Negro Improvement Association, were on the rise. Furthermore, the formation of the League of Nations in Versailles, the founding of the Comintern in Moscow, and the gathering of the first Pan-African Congress in Paris highlighted the growing importance of international relations.

In the United States, where the wartime rhetoric of " 100 Percent Americanism" continued to reverberate, large segments of the political establishment eyed this postwar surge of internationalism with suspicion. The Red Scare, Congress's refusal to join the League of Nations, and the passage of the Immigration Act of 
1924 signalled a return to American isolationism. Meanwhile, though, leading figures in black America seized upon another trope of the wartime rhetoric - that of self-determination - in order to agitate for various nationalist and internationalist models of social organization that would give a collective identity and voice to disenfranchised people of colour.

Among the more radical black internationalists of the time were two influential politicians of West Indian extraction: Cyril Briggs, the founder of the Marxist African Blood Brotherhood, who in 1921 called for "a federation of all existent Negro organizations" that would be "governed and directed by a central body" (qtd. in Stephens 1998: 599); and the flamboyant Marcus Garvey, who, a year earlier, had unveiled his plans for a Black Empire that was based on the tenets of separatism, racial purity, and race solidarity. Briggs's advocacy of a Negro Federation, which was rooted in notions of communist internationalism and the nineteenthcentury Black Nationalism of Marcus Delany, provide important backdrops for McKay's Home to Harlem and Larsen's Quicksand, both of which feature protagonists who struggle to ground their identities in terms of nationality and race.

In Home to Harlem, Ray's identity as a Haitian is shaken when the US American occupation of his island nation lands him, as he puts it, "in the quivering heart of a naked world whose reality was hitherto unimaginable" (150). Educated, French-speaking, and a citizen of a formerly independent nation, Ray finds himself confronted with the unsettling reality that common African American railroad workers "claimed kinship with him" (153). And in a near reversal of Ray's forced displacement, Helga, the daughter of an Afro-Caribbean father and a Danish immigrant mother, voluntarily leaves the States for "different, strange places," where she hopes to find the approval and understanding that she believes African American society had withheld from her (57).

In the United States the origins of the term "transnational" can be traced back to 1916, when The Atlantic Monthly published Randolph Bourne's essay "TransNational America," which argued that the war-induced fear of so called hyphenated-Americans had revealed the failure of the melting pot theory. In his essay, Bourne calls upon the United States to abandon its futile quest to "Anglo-Saxonize" its ethnically diverse population of immigrants and to conceive of itself as the "federation of cultures" that it has been since colonial days (1964: 119). As a nation of immigrants, Bourne argues, the United Sates must enable its inhabitants to "retain that distinctiveness of their native cultures" so that they are "more valuable and interesting to each other for being different" (1964: 117). Emphasizing that plurality, cultural cooperation, and international exchange had been the backbone of America's success, Bourne discerns the emergence of a cosmopolitan Americanness that "is coming to be, not a nationality but a transnationality, a weaving back and forth, with the other lands, of many threads of all sizes and colors" (1964: 119).

To be sure, as appealing as Bourne's picture of a transnational America may be, it comes fraught with generalizations and omissions. Most notably, Bourne sidesteps the problem of racism and fails to account for the experiences of Af- 
rican Americans as well as other members of the Black Diaspora, whose ethnic roots had been cut off as a result of slavery and who remained economically exploited and politically disenfranchised. Unlike the Cuban-born poet, José Martí, who two decades earlier celebrated Latin America's mestizo culture in "Nuestra America" (1891) and in "Mia Raza" (1893) advocated racial amalgamation, Bourne remains mute on questions of race in "Trans-National America".

Given the centuries-long experience of racism and exploitation, it is hardly surprising that few among Bourne's black contemporaries seem to have taken explicit note of "Trans-National America". Among those who did, though, was the influential Howard University professor, Alain LeRoy Locke, who considered himself "a cultural cosmopolitan, but perforce an advocate of cultural racialism as a defense counter-move for the American Negro, and accordingly, more of a philosophical mid-wife to a generation of younger Negro poets, writers, artists than a professional philosopher" (1935: 310).

In his introduction to the March 1925 edition of Survey Graphic, Locke makes a move very similar to that of Bourne's, arguing that black life in Harlem draws its vitality from the interactions of ethnically and culturally diverse peoples:

Here in Manhattan is not merely the largest Negro community in the world, but the first concentration in history of so many diverse elements of Negro life. It has attracted the African, the West Indian, the Negro American; has brought together the Negro of the North and the Negro of the South ... So what began in terms of segregation becomes more and more, as its elements mix and react, the laboratory of a great race-welding (1925b: 629).

Similar to Bourne, who considers the United States a "transplanted Europe" and a "world-federation in miniature" (1964: 121), Locke views Harlem as the epicentre of the Black Diaspora, which on a cultural plane has "the same rôle to play for the New Negro as Dublin has had for the New Ireland or Prague for the New Czechoslovakia" (1925b: 630). Adapting Bourne's argument that "it is for the American of the younger generation to accept this cosmopolitanism, and carry it along with self-conscious and fruitful purpose" (1964: 122), Locke describes the New Negro as "an augury of a new democracy in American culture" and "the advance-guard of the African peoples in their contact with Twentieth Century civilization" (1925a: 633). At least in theory, then, the United States seemed singularly positioned to provide the world with models of transnationality that might overcome ethnic strife, nationalistic tendencies, and imperial ambitions. Seventeen years later, on the heels of the United States' entry into the Second World War, Locke renewed his call for true racial integration, arguing that "this feeling that all who are here have a hand in the destiny of America ... will make for a finer spirit of integration than any narrow 'Americanism' or forced chauvinism" (1942: 334). Moreover, observing that "vague historic idealisms ... have provided the fuel for the European flame," Locke, again adapting a line from Bourne's "Trans-National America," conjectures that for the "latest" wave of refugees to 
reach America's shores "the lesson of this war" will likely be "a vivid realization of their transnationality, a new consciousness of what America means to them as a citizenship in the world" (1942: 334).

As Larsen's portrayal of Helga in Quicksand and McKay's depiction of Ray in Home to Harlem indicate, though, the forging of transnational identities visà-vis the longstanding "black-and-white" history of race relations in the United States remained an exceedingly difficult task (Stephens 1998: 593). Written and set during the volatile interwar years, Quicksand and Home to Harlem complicate and expand upon Bourne and Locke's accounts of "our changing ideal of Americanism" (Bourne 1964: 115) as "a citizenship of the world" (Bourne 1964: 123) by exploring how the transnational experience of moving away from, into, and between communities transforms existing identity concepts and creates spaces for the generation of self-definitions that are not bound by traditional notions of national, ethnic, racial, and familial belonging.

Throughout Quicksand Helga wrestles with essentialist notions of race, heritage, and culture that repeatedly compel her to view herself as a tragic mulatto, who may be tolerated but never truly belongs. At the same time, however, Helga's feeling that "[s]he could neither conform, nor be happy in her unconformity" (7) compels her to become a woman-in-motion who defies societal expectations. Her compulsive mobility, though often painful on a personal level, undermines restrictive conceptualizations of belonging and allows her to enact a mixed-race subjectivity that expands and confounds established identity categories. When the reader first meets Helga, she has already decided that she can no longer bear her black college's paternalistic "policy of uplift" as well as its "air of self-righteous and intolerant dislike of difference" (5). And she has also resolved to break her engagement with a fellow instructor, whose family, she suspects, has long been troubled by her conspicuos lack of familial ties. "Negro society," she believes to have learned, "was as complicated and as rigid in its ramifications as the highest strata of white society. If you couldn't prove your ancestry and connections, you were tolerated, but you didn't belong" (8).

Haunted by her self-identification as a "despised mulatto," she quits her job and heads North to her hometown of Chicago where she, although rudely rebuffed by her uncle's new wife, regains a sense of self amidst the multitude of people on the streets. Engulfed by "the moving multi-colored crowd" Helga is momentarily overcome by "a queer feeling of enthusiasm, as if she were tasting some agreeable, exotic food - sweetbreads, smothered with truffles and mushrooms - perhaps. And oddly enough, she felt, too, that she had come home. She, Helga Crane, who had no home" (30). Helga's feeling of belonging in the very heart of a bustling metropolis marked by anonymity, heterogeneity, and the allure of the exotic speaks to her evolving sense of self as part of a larger movement toward urbanity and cosmopolitanism. Predictably, her days filled with "the leisure, the walks, the lake, the shops and streets with their gay colors, their movement" are cut short by her inability to find reputable employment in Chicago (32). An editing job for a "prominent 'race' woman," who advises her "not to mention that 
her people are white" (40), eventually takes her to Harlem where "again she had had that strange transforming experience, this time not so fleetingly, that magic sense of having come home" (43).

Echoing Locke's description of Harlem as "the exotic fringe of the metropolis" which "draws the connoisseur in diversion as well as the undiscriminating sightseer" (1925b: 628), Larsen represents Harlem as a site of black consumerism, socializing, and entertainment that is set apart from white Manhattan. Sensing "the forces that make a group known and felt in the world" (Locke 1925b: 630), Helga comes to see herself as a Harlemite rather than a New Yorker, for "the sober mad rush of white New York failed entirely to stir her" (45). Resolving "some day ... to marry one of those alluring brown and yellow men who danced attendance on her," Helga disavows her ties with "that white world, so distant so.... No, not at all did she crave, from those pale and powerful people, awareness. Sinister folk, she considered them, who had stolen her birthright" (45).

In due course, however, Helga grows "discontent" and loses "confidence in the fullness of her life" (47). As her fascination with Harlem subsides, Helga feels annoyed by incessant talk about the "race problem"(46) and becomes irritated by her friend, Anne Grey, who professes to hate white people, yet apes their clothes and their manners and dislikes "the songs, the dances, and the softly blurred speech of the race" (48). Nevertheless, Harlem continues to present Helga with images of racial and cultural plurality that appear conducive to the development of what Randolph Bourne calls a "cosmopolitan attitude" (1964: 121). At one of Harlem's many nightclubs Helga notices "black eyes in white faces, brown eyes in yellow faces, gray eyes in brown faces, blue eyes in tan faces. Africa, Europe, perhaps with a pinch of Asia, in a fantastic motley of ugliness and beauty, semi-barbaric, sophisticated, exotic, were here" (52). This pastiche speaks to Bourne's sense that "America is coming to be, not a nationality but a transnationality, a weaving back and forth, with the other lands, of many threads of all sizes and colors" (1964: 119). Viscerally affected by the sensual scene of moving bodies, Helga makes "a conscious effort" to maintain her outsider position, cloaking herself "in a faint disgust" (59). But even though she admits her admiration for the socialite Audrey Denney, who has "the assurance, the courage, so placidly to ignore racial barriers and give her attention to people," Helga follows through with her plan to go to Copenhagen, where, she naively surmises, "there are no Negroes, no problems, no prejudice" (62).

Sure enough, Helga's attempt to forge "a broader, deeper" kind of kinship with her Danish relatives is undercut from the start by Denmark's colonial heritage (55). Prior to the sale of the Danish West Indies to the United States in 1916, the Colonial Exhibition of 1905 at Tivoli Gardens had led to a resurgence of colonial pride in Copenhagen, which manifested itself in the fact that it became fashionable for wealthy families to hire black nannies from the West Indies (Lunde and Stenport 2008: 238). Helga does not serve her Danish relatives as a nanny, but she certainly satisfies their desires for an exotic other. Clad by her aunt in "bright things ... striking things, exotic things" (68) she becomes "a curiosity, a stunt, at which people came and gazed" (71). 
For two years Helga revels in her role as the exotic other and even decides to retain her American accent for emphasis, until she attends a vaudeville show that features two American "Negroes" performing old ragtime songs. Ashamed and appalled by the avidity with which her white Danish suitor drinks in the minstrel show, Helga rebuffs his subsequent marriage proposal and returns to Harlem. Similar to Jake in McKay's Home to Harlem, who, during East London's race riots, runs "away from the kind-heartedness" of his English girlfriend to the streets of Harlem "with their chocolate brown and walnut brown girls" (McKay 2000: 7-8), Helga leaves Copenhagen, where she had met "only pale serious faces when she longed for brown laughing ones" (92).

Considered a legal citizen in Denmark and the United States, Helga never attains a sense of being Danish, American, or both. Characteristically, she does not feel drawn to "the good old-fashioned Danish songs" (80) and maintains "a fine contempt for the blatantly patriotic Black Americans" (96). Still, whilst her initial sense of being "neither black nor white" remains, life among the "Nordics" seems to have strengthened her cultural self-identification as an African American (99). In the end, though, Helga's ill-conceived attempt to cement her tenuous embrace of African American identity by marrying a conservative preacher and moving to an all-black hamlet in Alabama underscores the limits of her imagination, which posits African Americanness as essentially rural, backward, god-fearing, parochial, and patriarchal. As the novel closes, Cheryl Wall observes, Helga "is trapped by her stereotyped view of what "“true' Black culture is" (1986: 111).

Before the backdrop of the rise of Nativism in post-WWI America, Larsen's portrayal of her multi-racial and multi-ethnic protagonist in Quicksand challenges essentialized concepts of racial and ethnic purity. Transnational mobility renders old notions of stable group and personal identities untenable, the novel underscores by showing how Helga's confused attempt to seek refuge in the certainties "of far-off simpler centuries" subjects her to oppressive patriarchal ideologies of old (114). In the unsettling final chapters, Quicksand illustrates the pitfalls of Helga's "aspiration toward the regaining of simple happiness, a happiness unburdened by the complexities of the lives she had known" (114). Unlike Ray, who comes to reject outdated notions of a stable identity in favour of a transnational, diasporic mode of being, Helga falls into the trap of seeking to attain lasting "serenity" and "stability" through marriage and domesticity (116).

Ray in McKay's Home to Harlem does overcome his own prejudices about the "ten millions of suppressed Yankee "coons"” (107). But even though he forges an unlikely bond with Jake, an uneducated, life-loving member of the black working classes, he never fully associates himself with the life and racial politics of Harlem. Like Helga, Ray considers himself "a misfit" throughout his time in Harlem and in due course sets sail for distant Europe (109). When the reader first meets Ray about half-way through the novel, he is painfully aware of being a displaced and powerless colonial subject of the United States: "Ray felt that as he was conscious of being black and impotent, so, correspondingly, each marine down in Hayti must be conscious of being white and powerful" (154). Once a "proud son 
of a free nation," Ray remembers how he "used to feel condescendingly sorry for those poor African natives; superior to ten millions of suppressed Yankee 'coons.' Now he was just one of them and he hated them for being one of them" (107). Keenly aware that in the segregated United States race had become his primary identity marker, Ray quarrels with his sense of "social morality" that tells himself "he ought to love" the men with whom he toils on the railroad (109). Neither blind nationalism nor uncritical racial allegiance, the novel suggests, are appropriated responses to Western imperialism and white supremacy.

Of course, Ray is not the only one harbouring feelings of condescension toward people of different classes, ethnicities, and nationalities. Jake, the novel's narrator relates, "was very American in spirit and shared a little of that comfortable Yankee contempt for poor foreigners. And as an American Negro he looked askew at foreign niggers. Africa was jungle, and Africans bush niggers, cannibals. And West Indians were monkey-chasers" (92). Obviously, such chauvinistic sentiments are far removed from the "cosmopolitan attitude" and "great racewelding" that Bourne and Locke respectively discerned on the immediate horizon of modern history. It thus falls upon Ray to bring his working-class friend "into contact with Twentieth Century civilization" by providing Jake with the necessary personal and historical contexts to understand himself as part of the Black Diaspora (Locke 1925a: 633).

As he learns about the long Haitian struggle for independence and "for the first time" hears "the name Toussaint L'Ouverture," Jake exclaims, "A black man! A black man! Oh, I wish I'd been a soldier under such a man" (90). In this highly symbolic scene, Jake, who had once served in the same US army that occupied his new friend's island nation, comes to reconsider his loyalties in the historical struggles between colonizer and colonized. Jake does not, to be sure, become a revolutionary. But Ray's subsequent accounts of his father's arrest and brother's murder at the hands of US marines brings Jake to the realization that "we may all be niggers aw'right, but we ain't all the same" (110). Thus Jake comes to affirm his new friend's experience as a colonial subject while simultaneously claiming him as a member of the larger race. By "writing the West Indian immigrant narrative as a narrative of Haitian exile," John Lowney notes, "McKay suggests a common ground for cross-cultural dialogue among African American and Caribbean critics of American imperialism" (2000: 426). The upshot of this cross-cultural dialogue, as Michelle Stephens has argued, is that Jake's concept of his "own nationality, both as an American and a Harlemite" gives way to "a more internationalist imagining of both racial home and his own black masculinity" (2005: 152). "Jake felt like one passing through a dream, vivid in rich, varied colors," the narrator relates (92). "It was a revelation beautiful in his mind. That brief account of an island of savage black people, who fought for collective liberty and was struggling to create a culture of their own" (92).

Meanwhile, living in Harlem, working on the railroad, and hanging out with Jake, Ray becomes increasingly critical of his European book-learning. Reflecting on the works of his "old spiritual masters" Anatole France, Henrik Ibsen, 
George Bernhard Shaw, and H.G. Wells, Ray senses that their visions of "ultimate social righteousness" had failed and "he had lived over the end of an era" (158). What is needed, he concludes, are new voices with a "reservoir of words too terrible and too terrifying for nice printing" (158). Consequently, Ray begins to formulate the credo of the New Negro, "who wishes to be known for what he is, even in his faults and shortcomings ... and resents being spoken of as a social ward or minor" (158). A little later, still animated by his dawning sense of being a New Negro in a modern world of postwar possibilities, Ray lectures a member of Harlem's educated elite:

"No, modern education is planned to make you a sharp, snooty, rooting hog. A Negro getting it is an anachronism. We ought to get something new, we Negroes. But we get our education like-like our houses. When the whites move out, we move in and take possession of the old dead stuff. Dead stuff that this age has no use for" (169).

Noting that European models of higher education tend to reinforce divisions along lines of class, nationality, and race, Ray gives voice to what Locke called "the growing group consciousness of the dark-peoples and ... their common interests" (1925a: 634). More intriguingly, though, Ray's self-critical reflections entail a radical critique of Western nationalism that implicates it in the quest for global domination:

"Races and nations were things like skunks, whose smell poisoned the air of life. Yet civilized mankind reposed its faith and future in their ancient, silted channels. Great races and big nations! There must be something mighty inspiring in being the citizen of a great strong nation. To be the white citizen of a nation that can say bold, challenging things like a strong man" (106).

In marked distinction to Locke, who envisioned Harlem competing on a cultural plane with European capitals, and Marcus Garvey, who dreamed of a strong black empire, Ray seeks to counter that "grand business of civilization" by upholding the possibility of a post- or transnational communalism. Contrasting the corrupting narrative of white civilization's claim to power with "the keen ecstatic joy a man feels in the romance of being black," Ray locates the possibility of non-repressive communalism among "all the black and brown hybrids and mongrels, simple earthloving animals, without aspirations toward national unity and racial arrogance" (17).

Just as he is beginning to find his proto-postcolonial voice, Ray decides to leave Harlem, fearful that "[s] oon he would become one of the contented hogs in the pigpen of Harlem, getting ready to litter little black piggies" (184). In rejecting the prospect of marriage with his girlfriend, Agatha, Ray seeks not only to preserve his personal independence, but also to evade the discourse of normative heterosexual domesticity through which nation states naturalize and legitimize narratives of racial citizenship. As "slaves of the civilized tradition," he and Aga- 
tha, Ray muses, were bound to succumb to the "mind's hankering after the pattern of respectable comfort" (185). George Hutchinson's observation that Larsen's Quicksand "raises essential ethical challenges to the discourse of family that still informs the deep structure of American racial ideology" (2007: 82) is thus equally applicable to McKay's Home to Harlem, even though the two novels' protagonists are compelled to take opposite paths, leading them into the worlds of tragedy and the picaresque respectively.

"Going away from Harlem," Ray once more reflects on its "brutality, gang rowdyism, promiscuous thickness" as well as the materialism and lack of political resolve of its educated denizens (187). But then he tempers his disillusionment, recalling that he "had known happiness, too, in Harlem, joy that glowed gloriously upon him like the high-noon sunlight of his tropic island home" (187). Tenuously conjoined, Haiti and Harlem form the exile's memory as he embarks on his journey to the very continent from whence that "grand business called civilization" had emanated (107).

Ray's departing thoughts prefigure "the world of denationalized black colonial migrants" (Stephens 1998: 603) that is the focus of McKay's second novel, Banjo, and bespeak Homi Bhabha's contention that it is from the peripheries and margins that the "diasporic come to change the history of the nation" (1994: 234). Thus, unlike Larsen's Helga, whose retreat into rural parochialism effectively terminates the development of a transnational identity, McKay's Ray appears to be joining "the advance-guard" of the Black Diaspora that is about to bring post-war Europe into "contact with Twentieth Century civilization" (Locke 1925a: 633). Not, however, by imitating the tightly scripted cultural nationalisms of the West, but by deploying subversive images of "black and brown hybrids and mongrels... without aspirations toward unity and racial arrogance" (107). If, as Henry Louis Gates has argued, Alain Locke transformed the trope of the New Negro "into an apolitical movement of the arts" that sought to present white audiences with "a Negro who was 'just like' every other American," nonconforming characters such as Claude McKay's Ray and Nella Larsen's Helga appear to recover some of "the militancy [originally] associated with the trope" (1988: 147). At minimum, the multiethnic, -racial, and -national characters of Ray and Helga serve to unsettle prevalent ideas of what constitutes an American.

In Banjo: A Story Without a Plot (1929), McKay's sequel to Home to Harlem, readers again encounter Ray, who has meanwhile arrived in France. Sitting on the docks of Marseilles, which in the 1920s had become a center of the francophone Negritude movement, Ray considers himself a product of the port's thoroughfares. "It was," Ray contemplates, "as if every country of the world where Negroes lived had sent representatives drifting into Marseilles" (2003: 68). Ray's reflections in the French port of exchange further accentuate the transnational tension between uprootedness and regrouping that underlies both Home to Harlem and Quicksand. As Homi Bhabha observes in The Location of Culture, on the one hand, transnationalism denotes "the scattering of the people across countries" and "the uprooting of communities and kin" that isolate the individual and 
render her vulnerable (1994: 230). On the other hand, transnationalism signifies "a time of gatherings" that brings together cultures, languages, histories, ideas, and discourses (Bhabha 1994: 230). Home to Harlem and Quicksand serve notice that such gatherings of exiles, refugees, migrants, and immigrants are marked by conflicts and unequal power relationships. At the same time, though, Larsen and McKay's transnational novels show that meetings of strangers hold the promise of increased understanding across ethnic, race, and class lines. Not, to be sure, by way of "salvation" but through encounters in locations such as Harlem where "emergent identifications and new social movements are played out" in all their complexities (Bhabha 1994: 234).

\section{References}

Bhabha, Homi (1994) The Location of Culture. London: Routledge.

Bourne, Randolph (1964) "Trans-National America." In: Resek, Carl (ed.) War and the Intellectuals: Collected Essays, 1915-1919. New York: Harper, 107-123.

Davis, Thadious M (1994) Nella Larsen, Novelist of the Harlem Renaissance: A Woman's Life Unveiled. Baton Rouge: Louisiana State University Press.

Doyle, Laura (2005) "Transnational History at Our Backs: A Long View of Larsen, Woolf, and Queer Racial Subjectivity in Atlantic Modernism.” Modernism/modernity 13 (3), 531-559.

Du Bois, W.E.B. (1995) “The Color Line Belts the World.” In: Lewis, David (ed.) W.E. B. Du Bois: A Reader. New York: Holt, 42-43.

Du Bois, W.E.B. (1996) The Souls of Black Folks. New York: Penguin.

Du Bois, W.E.B. (1928) "Two Novels: Nella Larsen, Quicksand \& Claude McKay, Home to Harlem." Crisis 35, 202.

Edwards, Brent Hayes (2003) The Practice of Diaspora: Literature, Translation, and the Rise of Black Internationalism. Cambridge: Harvard University Press.

Fishkin, Shelley Fisher (2005) "Crossroads of Cultures: The Transnational Turn in American Studies: Presidential Address to the American Studies Association, November 12, 2004." American Quarterly 57 (1), 17-57.

Gates, Henry Louis Jr. (1988) "The Trope of a New Negro and the Reconstruction of the Image of the Black." Representations 24, 129-155.

Hutchinson, George (2007) "An End to the Family Romance: Nella Larsen, Black Transnationalism, and American Racial Ideology.” In: Campbell, James, Mathew Guterl, and Robert Lee (eds.) Race, Nation, and Empire in American History. Chapel Hill, NC, North Carolina University Press, 55-72.

Larsen, Nella (1987) Quicksand. In: McDowell, Deborah (ed.) Quicksand and Passing. New Brunswick, NJ: Rutgers University Press, 1-142.

Locke, Alain (1925a) "Enter the New Negro." Survey Graphic 6 (6), 631-634.

Locke, Alain (1925b) "Harlem." Survey Graphic 6 (6), 628-630.

Locke, Alain (1935) "Values and Imperatives." In: Kallen, Horace M. and Sidney Hook (eds.) American Philosophy Today and Tomorrow. New York: Lee Furman, 312-333.

Locke, Alain (1942) "Minority Issues in American Democracy" In: Locke, Alain and Bernhard J. Stern (eds.) When Peoples Meet: A Study in Race and Culture Contacts. New York: Progressive Education Association, 328-342.

Lowney, John (2000) "Haiti and Black Transnationalism: Remapping the Migrant Geography of Home to Harlem." African American Review 34 (3), 413-429. 
Lunde, Arne and Anna Westerstahl Stenport (2008) "Helga Crane's Copenhagen: Denmark, Colonialism, and Transnational Identity in Nella Larsen's Quicksand." Comparative Literature 60 (3), 228-243.

McKay, Claude (2005) "A Negro to His Critics.” In: Parascandola, Louis (ed.) Look for Me all Around You: Anglophone Caribbean Immigrants in the Harlem Renaissance. Detroit: Wayne State University Press, 299-305.

McKay, Claude (2003) Banjo: A Story Without a Plot. London: X Press.

McKay, Claude (2000) Home to Harlem. London: X Press.

Stephens, Michelle A. (1998) "Black Transnationalism and the Politics of National Identity: West Indian Intellectuals in Harlem in the Age of War and Revolution." American Quarterly 50 (3), 592-608.

Stephens, Michelle A. (2005) Black Empire: The Masculine Global Imaginary of Caribbean Intellectuals in the United States, 1914-1962. Durham, NC: Duke University Press.

Wall, Cheryl A. (1986) "Passing for What? Aspects of Identity in Nella Larsen's Novels." Black American Literature Forum 20, 97-111.

Karsten H. PieP is a full-time faculty member of Union Institute \& University's Interdisciplinary Studies Program in Cincinnati, Ohio, where he teaches seminars in Western intellectual history, protest literature, and interdisciplinary theory. He is the author of Embattled Home Fronts: Domestic Politics and the American Novel of World War I (Rodopi 2009). His articles have appeared in such journals as Comparative Literature and Culture, Cultural Logic, New German Review, Papers on Language and Literature, and Studies in American Fiction.

Address: Karsten H. Piep, Interdisciplinary Studies Program, Union Institute \& University, 440 East McMillan Street, Cincinnati, Ohio 45206. [email: karsten.piep@myunion.edu] 
